\title{
The use of historical sources in a multi-layered methodology for karez research in Turpan, China
}

\author{
Sophie Barbaix ${ }^{1,2,4,5}$ (D) Alishir Kurban ${ }^{1,4,5,6}$ (D) Philippe De Maeyer ${ }^{1,3,4}$ (D) . \\ Xi Chen ${ }^{1,4,5,6}$ (ID) Jean Bourgeois ${ }^{2,4}$ (D)
}

Received: 7 September 2020 / Accepted: 16 October 2020 / Published online: 18 November 2020 (c) Springer Nature B.V. 2020

\begin{abstract}
In this article, we will present an overview of possible research methods to handle historical sources, in the specific case of karez landscapes. A karez system is an underground water collection system, prevalent in the Turpan basin of China. Sources and the associated methodology have become more important today, because of contemporary issues such as modernisation, urbanisation and agricultural expansion. These problems make it harder to read the landscape, which is why we have to start extracting our data from maps, reports, photographs, and satellite imagery. We will give a short overview of sources, each with an explanation of their processing method. Despite certain cautions that should be taken into account, these methods clearly complement the current state of knowledge on the Turpan karez. As this paper is part of a special issue, Water History in the time of COVID-19, it has undergone modified peer review.
\end{abstract}

Keywords Karez $\cdot$ Turpan $\cdot$ China $\cdot$ Historical sources $\cdot$ Methodology

This paper is part of a special issue, Water History in the time of COVID-19. This issue was designed to be a venue for scholars who had been planning on presenting their research at academic conferences that were postponed or cancelled due to the virus. We recognize the vital importance of conference presentations for us to get feedback on work in progress, to share promising projects, and to begin meaningful conversations with peers. This special issue has undergone modified peer review, and these essays are to be seen as works in progress rather than final results; the authors welcome your feedback, conversation, and engagement.

Alishir Kurban

alishir@ms.xjb.ac.cn

1 Xinjiang Institute of Ecology and Geography, Chinese Academy of Sciences, 818 South Beijing Road, Urumqi 830011, Xinjiang, China

2 Department of Archaeology, Ghent University, Sint-Pietersnieuwstraat 35, B-9000 Ghent, Belgium

3 Department of Geography, Ghent University, Krijgslaan 281, S8, B-9000 Ghent, Belgium

4 Sino-Belgian Joint Laboratory for Geo-Information, Ghent and Urumqi, Belgium

5 University of Chinese Academy of Sciences, 19(A) Yuquan Road, Shijingshan District, Beijing 100049, China

6 Research Center for Ecology and Environment of Central Asia, Chinese Academy of Sciences, 818 South Beijing Road, Urumqi 830011, Xinjiang, China 


\section{Introduction}

The landscape of the arid oasis of Turpan is characterized by thousands of karez wells dotting the surface (Figs. 1,2). The karez underground water network was once the main water supply system in the area. Many questions concerning the Turpan karez and its related water landscape remain. To study this, a combination of documentary sources as well as fieldwork is necessary. However, there are very few primary documents at our disposal, making field survey the most used research method to gather information. While fieldwork provides ample data not garnered otherwise, it also leaves many blanks, and the study of these remaining sources gains importance. Over time, increasing urbanisation, expanding agricultural plots and an intensive reshaping and exploiting of the landscape in the

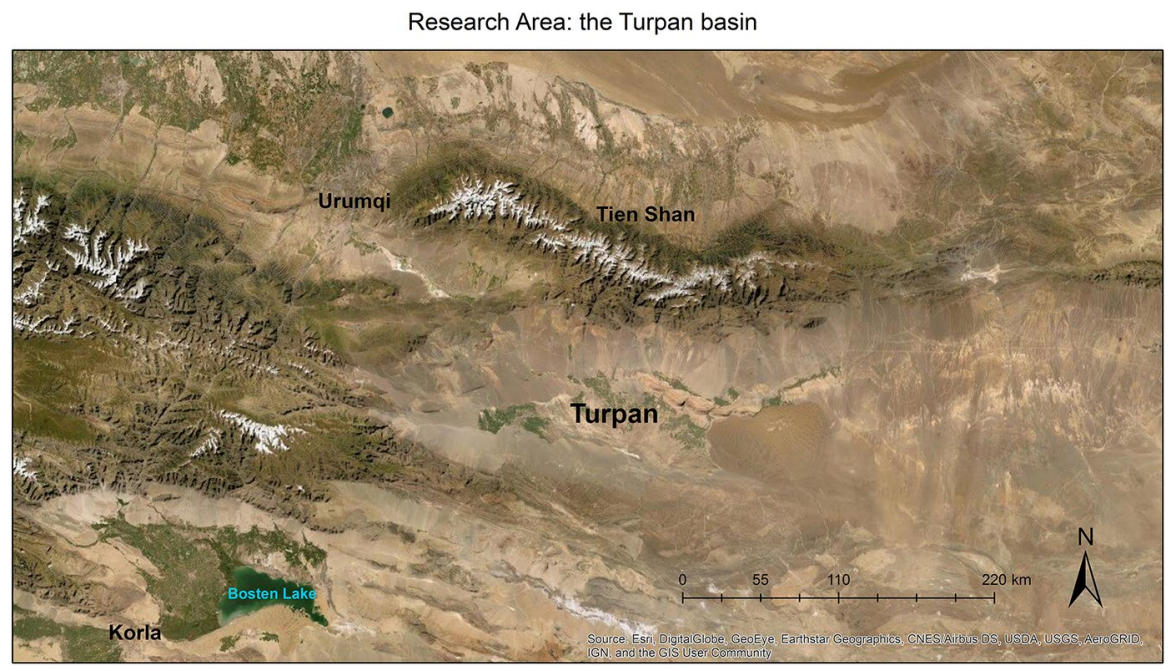

Fig. 1 Localisation of the Turpan basin research area (Esri basemap, own figure)

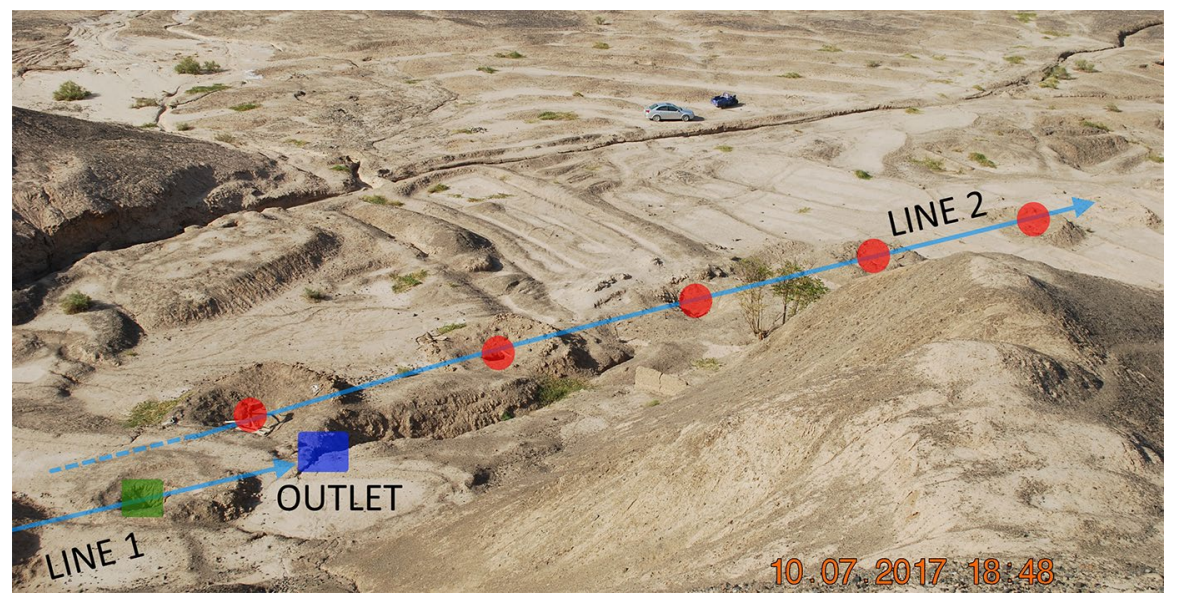

Fig. 2 View of a typical landscape with the heads of two karez lines (circles and rectangles) and one karez outlet in valley 1 of Murtuq, Turpan. View towards the northwest (own photo) 
context of China's Western Development program, have made the landscape less readable and many traces have been lost (Lai 2002). Historical sources can be used in an attempt to fill these gaps. Often, however, the value of these historical sources is overlooked. In this article, the usefulness and method for handling these historical sources will be examined. We will give a glimpse of the useful information regarding the Turpan water landscape that was gathered this way.

\section{What are karez and why this research?}

A karez (qanat, kariz, kan'erjing or 坎儿井) is an underground tunnel with a gentle slope that leads water from the higher mountainous areas to the lower-lying fields, without evapotranspiration. The water is collected in a catchment section, transported through a conveyance section and is distributed through open-air channels, canals and ponds connected to the karez outlet (Fig. 3). On the surface, only the heads of the vertical shafts are visible. These vertical wells are characteristic for karez systems, since they are essential for the construction, ventilation and maintenance (Lombard 1991; Trombert 2008; Mostafaeipour 2010; $\mathrm{Hu}$ et al. 2012; Mingjiang 2015). Considering the hydrology, the gently sloping topology and the climate of the Turpan Basin, the karez have played an important role in the irrigation of the fields in the area. However, since 1960 and especially since 1990, more and more karez ran dry and are abandoned. The water demand has risen, due to population growth and the agricultural expansion, stimulating uncontrolled (mechanical) well digging and ultimately lowering the groundwater table (Tolmbok 2015). It is estimated that by 2030, there could be no functioning karez left in Turpan (Bertrand 2010; Hu et al. 2012; $\mathrm{Fu}$ et al. 2014; Aihua 2015). The history of the Turpan irrigation system still has many open questions. Few primary sources survived or many are inaccessible. Karez remains in the field are threatened by increasing modernization and abandonment. Given the lack of primary sources (old testimonies) and the difficulties concerning field data gathering, however, other historical sources have proven to be able to enrich the history and the evolution of the water landscape.

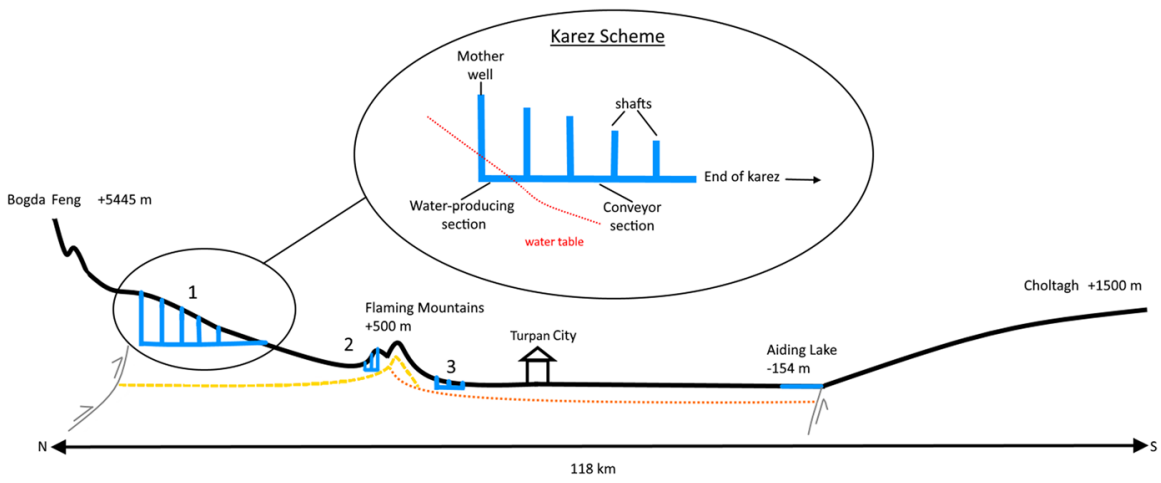

Fig. 3 Schematic drawing of a karez system in the Turpan basin (own figure) 


\section{The multi-layered methodology}

Historical sources alone cannot replace all other data sources. They are a small part of a well-known and well-practised multi-layered methodology from landscape research. This view is often adopted in ecosystem, historical, geomorphological and archaeological landscape research (Howard et al. 2019). The idea is generally the same. By incorporating the natural/physical characteristics and also the social, economic, political, traditional and mental aspects of a landscape, in casu a water landscape, links between these fields and the subject at hand can be revealed. We favour a process of emergence over primacy in this multi-layered approach, without any prechosen focus. Some authors can favour a political view (Massey 2005) or are starting from a social perspective (Evans 2003) and sometimes there is still a case of ecological determinism (Liu et al. 2014). Neither of these views is wrong, but by trying to let the landscape interactions reveal themselves instead of starting from a specific (political or any other) landscape is meant to add another layer of inquiry. If some connections emerge, one should ask the question: "why do these relations specifically reveal themselves so prominently?". It could be because of a bias of the collected data or just because these were preserved better, maybe because they are deemed more valuable. This is not an attempt to claim this approach is more objective, but rather proposed as a different way to incorporate the inherent subjectivism of research. Historical sources, though seldom being fully objective, fit perfectly in this approach, but need a critical analysis. They can handle a wide array of subjects, have different scales and can shed light on less visible periods.

\section{The historical sources}

\section{Maps}

\section{Types of maps}

Several researchers have already touched upon the merit of these documents for historical research (Jenny 2006; Petrie et al. 2019) and even karez research (Martínez-Santos and Martínez-Alfaro 2014). Depending on the research area, there are several types of historical maps available, including old topological maps, exploration maps, colonial maps or missionary maps. These are made by botanists, geographers, anthropologists, cultural historians and archaeologists during their exploration of Xinjiang and surrounding regions. Analysing these maps was particularly useful, because often they (a) are quite detailed with a large scale, (b) have an extensive legend, and (c) include uninhabited and generally uncharted terrain. There is no one go-to source to find historical maps. Exploration maps are often published together with reports, missionary maps are stored in the archives of said missions, colonial maps are often still preserved by governmental institutions. For the Turpan area, the most common and useful maps turned out to be exploration maps.

\section{Processing method}

Once a map has been located and digitized, it has to be geo-referenced. The lack of GPS data means this has to happen manually. If the map contains a coordinate grid, this could be 
used to connect the intersection to digital coordinate systems. However, caution is advised. Measuring errors are still possible and the accuracy of historical maps can be limited. For example, the maps made by the Hungarian-British explorer Sir Aurel Stein do have a grid, but it soon became clear that in bare land and mountainous regions there was a significant deviation due to Stein's cartographical technique and less frequent visits (Fig. 4). A sightbased geo-referencing is most advisable for this kind of old maps. This method designates recognizing points on the map and links them to features on modern maps and satellite imagery. The map needs to be transformed and thus a mathematical conversion is required. For the maps with the least deviancy, a second-order polynomial transformation is sufficient; for the other maps, higher orders or even 'splicing' are necessary (stretching the map to the relevant points with no regard for the geometric coherency of the original image). Once the geo-referencing is completed, the most relevant features are turned into vector data to facilitate its inclusion in other GIS processes.

\section{Historical criticism}

As with all historical sources, maps should be held to historical criticism (Howell and Prevenier 2001; Boone 2015). Firstly, special attention is paid to whether or not the map creator visited the area himself and which ambiguities on the part of the cartographer are possible. For example, Stein noted sources where there are nowadays karez outlets. It is possible Stein observed a karez outlet, but did not recognize it as such. Another ambiguity can be found in the names of locations and features. Foreign cartographers usually made

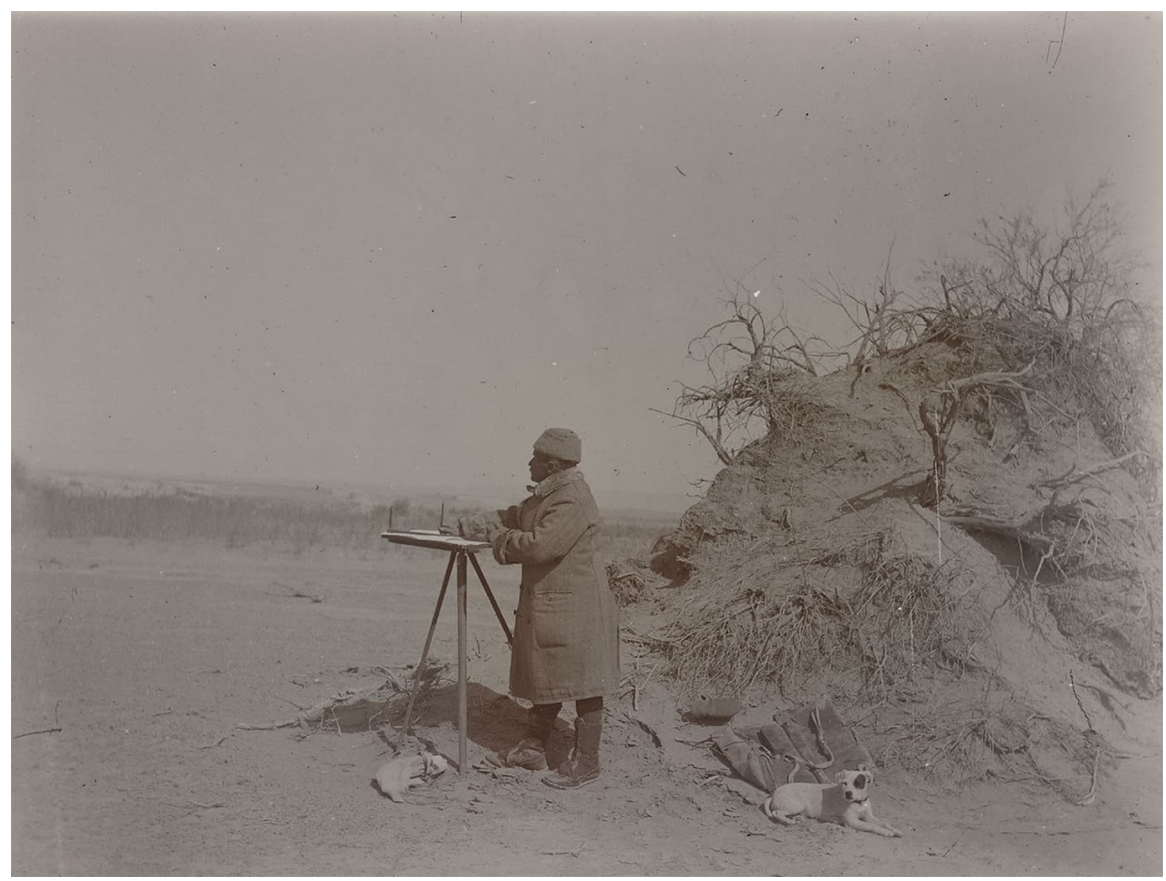

Fig. 4 Sir Aurel Stein at his plane table surveying in the Taklamakan Desert (British Library IDP Photo 392/28(739)) 
an approximation of the name that was used locally. The use of several alphabets (Cyrillic, Latin) or the use of complete other writing systems further complicated the case. Huang Wenbi, a Chinese archaeologist, mapped Turpan and tried to find the closest sounding Chinese logographics, while replacing the 'river' or 'city' part of toponyms with the Chinese word (Huang 1954a, b, Map 1). Simple mistranslations and misunderstandings are propagated in maps and conjoined reports (Jarring 1961, 1997; Matsui 2015). Secondly, some maps draw inspiration from other sources, increasing the chance of copying a mistake. Lastly, the effect of the interpretation of the cartographer on the structuring and drawing of the map and legend should not be forgotten. Nevertheless, historical maps remain useful information sources.

\section{Data extraction}

In total, we processed 9 maps. Locating past features or reconstructing past regions based on maps is called map regression. The information gathered from this map regression analysis includes:

- The course/presence of waterways in the past. The situation sometimes changed in the present (Figs. 5 and 6).

- The names or original meanings of toponyms, sometimes related to water (e.g. bulak, designating that this place was named after a natural spring).

- Historical routes.

- Past habitation and agriculture distribution.

- General presence and partial density of karez in the past.

One should not be tempted to conclude that certain features were not present, because they are not visible on the map. The lack of a feature on a map means nothing more than that nothing deemed worth mapping was observed. The feature could have not been observed or was not interesting enough to include it on a map.

\section{Photographs}

Old photographs can also provide additional information and are still underappreciated sources of historical information (Cabos 2018). They provide a view of the past landscape and attest to the presence of certain features and their condition at the time of the visit. Besides, they also allow a glimpse of the way that landscapes and other photography subjects were experienced by the photographers or the person who was directing them (Cabos 2018). Lastly, they are often the only remaining record for certain features and artefacts that have been destroyed, lost or vandalized (Falconer 2004). For China, and especially the Silk Road area, many nineteenth-twentieth century explorers deployed photography as one of their field tools. The rather heavy and impractical equipment and specific requirements necessary for its use, did not inhibit the adoption of photography in the field (Falconer 2004). This ignited a debate on the function of photography: as an illustrative reference guide, an objective archive or a conservation tool for endangered remains (Falconer 2004)?

Most relevant photographic archives do indeed date from the beginning of the twentieth century. Photography was not yet popular nor prevalent in Qing China, thus there are 


\section{River Network by Map Regression}

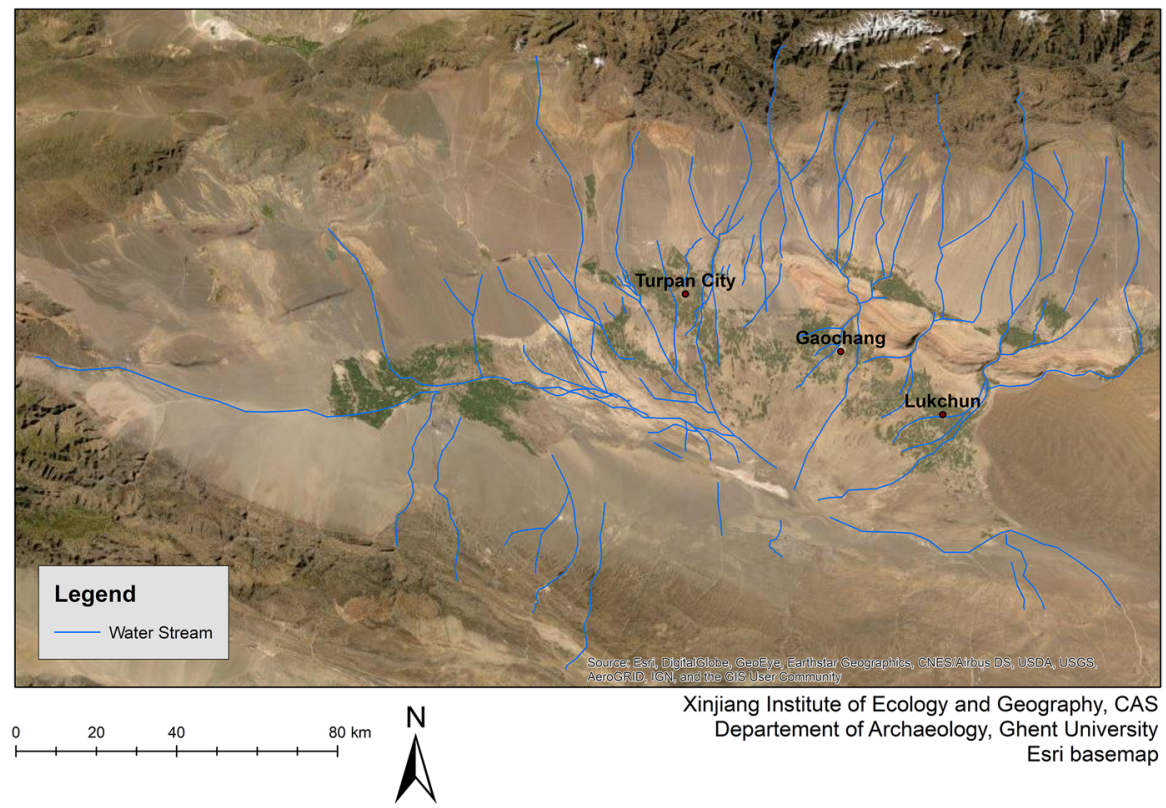

Fig. 5 Map of the river network as depicted on historical maps. The more people independently drew the same river, the bigger the chance that their observations were correct. The sources used for this map regression are added at the end of the bibliography (own figure)

no known great contemporary Chinese archives. Most collections stem from exploration campaigns. Notable attempts were made by the mission of Paul Pelliot, who hired Charles Nouette, a professional photographer. This is why the French mission photographs are of remarkable quality (Cabos 2018). Oldenburg also chose to be accompanied by a photographer, Samuil Dudin (Falconer 2004). Sir Aurel Stein likewise created an enormous collection of photographs, but himself only being an amateur photographer, as were his assistants, some plates resulted in badly lighted scenes - as he wrote in his personal diary. On the other hand, he used a rigorous registration system to organize his photographs, which is missing from the German photographic collection by Albert Grünwedel and Albert von Le Coq (Falconer 2004). For the Turpan area, many explorer's photo collections exist, but they are widespread and sometimes badly organized or uncategorized. Many photographs, however, are available online. Thanks to the Dunhuang project and the Staatliche Museen $z u$ Berlin, the entire collections of the German and British Turpan expedition have been digitized. Lilla Russell-Smith, Ágnes Kelecsényi, Ágnes Kárteszi, John Falconer, Éva Apor, Helen Wang, Luo Huaqing and colleagues have also done noteworthy work cataloguing other collections such as the Hungarian Academic Library Stein collection. The Russian collections, mainly located in the Hermitage and the Institute for Oriental Manuscripts, are slowly being organized and made available (Falconer 2004; Dreyer 2008; pers. comm). Other collections are located in the National Library in Beijing (China), the Toyo Bunko Kyoto Library (Japan), and the National Museum New Delhi (India). 


\section{Potential River System by the JAXA ALOS DEM}

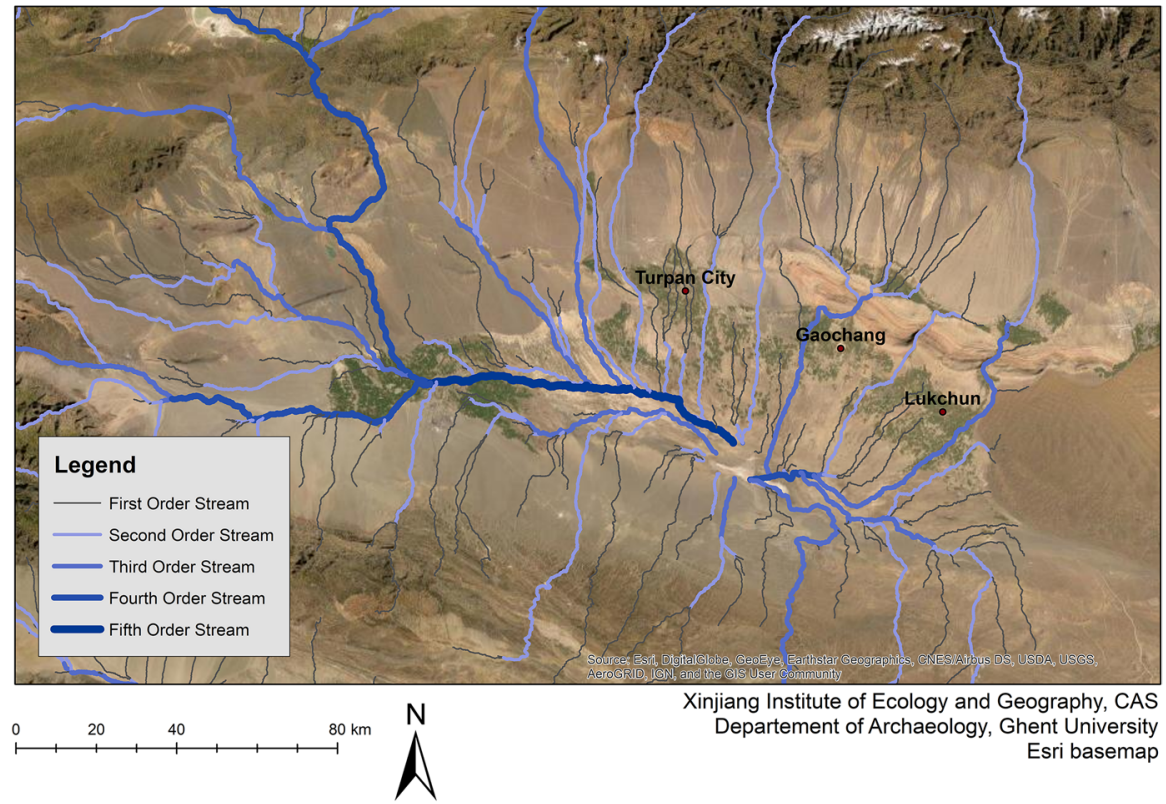

Fig. 6 A potential water network derived from a modern JAXA ALOS DEM, calculated with a 50,000 stream delineation threshold in ArcMap 10.3, shown on top of the Esri Basemap (own figure)

\section{Processing method}

Due to the (understandable) lack of EXIF-data, these photos had to be geotagged manually. Since this can be time-consuming and usually requires a degree of familiarity with the landscape, only the most relevant and beneficial photographs were chosen. The freely available ArcGIS toolbox, ArcPhoto (version 1.5.5) (https://www.arcgis.com/home/item. $\mathrm{html}$ ?id=578d358a575e4a8ea067a180e00b1325), allows for the manual positioning of these digitized photographs. If possible, modern pictures are taken in the field, from approximately the same spot (Fig. 7). This way, the same view can be compared, based on location. In total, 52 old photographs have been geo-located.

\section{Historical criticism}

After collecting the photographs, one should check if any information is available on how they were made. Certain developing techniques, e.g. the daguerreotype, can result in mirrored images. Luckily, this was not the case for the photos in this study. If the photos were taken from publications, they were possibly cropped. It might be useful to track down any original photo, glass plate or film roll, to check if this is the case. It turned out that Stein had indeed cropped some of his photos that had been published in Innermost Asia (Stein 1928a, b). Lastly, there remains a potential archival problem. Numbering and labelling of old photos could be wrong, too broad or missing entirely, resulting in certain relevant pictures missing. This is usually attributed to the loss of 


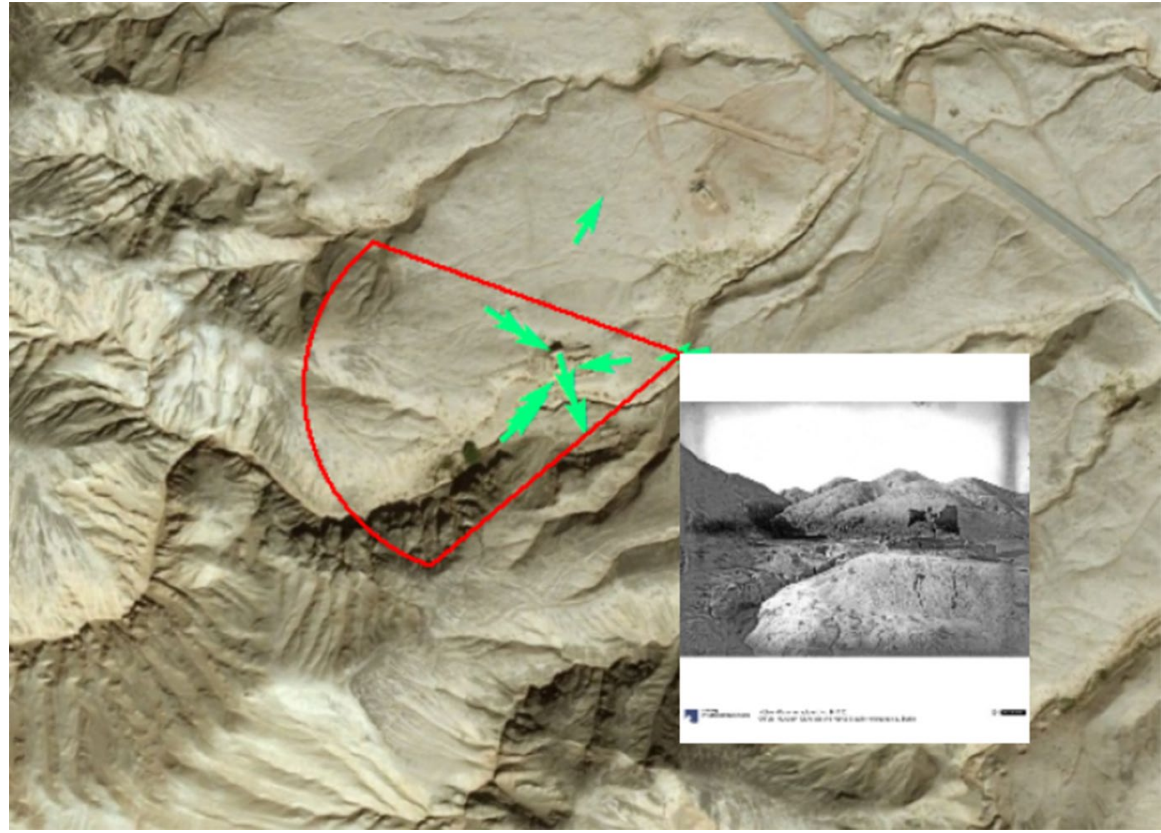

Fig. 7 Screenshot of the ArcPhoto toolbox in action. The green arrows show the position and direction of all the geotagged photographs of this area, the red cone symbolizes the view from one specific viewpoint and a thumbnail of the photograph is displayed. In this case the photograph is part of the SMB-digital collection in Berlin and shows the front of the Murtuq monastery ruin (own figure)

the original label through time. Depending on the size of the collection and time constraints, it might be fruitful to quickly pass through other parts of the collection. This was the case in the online collection of the Staatliche Museen zu Berlin (SMB-digital), where photos of the virtually unknown and unpublished valley 1 in Murtuq were unclearly labelled (https://www.smb-digital.de/eMuseumPlus). This can be corrected by being familiar with the terrain.

One should also keep in mind that there was a very selective photographing interest. The 'greatest' or most 'sensational' ruins were photographed by several explorers, while the building that might have been just right next to is not attested in any photographic evidence. Cabos points to the construction of a canon of Chinese Heritage and the fixing of a 'visual code' (Cabos 2018). This selective choice of subjects must be taken into account when going through the archives. Overview and landscape shots are rare, while great temples or the forest of stupas in Jiaohe have several photos. This is not only the case for these collections, but is a problem often encountered in photographic missions with different goals. It can even extend to aerial photography (Saunders 2009). People would photograph what they wanted to photograph, document and preserve. Most of all, many of the pictures were selected by the researchers to show to the public, once returned from the fieldwork, from a larger set. 


\section{Reports}

Old travel and exploration reports are often more detailed or give some specific information that was not deemed interesting enough to summarize in a map or a photograph. Therefore, checking out dusty tomes of these past adventures and explorations often gives some specific information, such as most cultivated crops, weather reports, location of markets, names and statuses of people commissioning karez, backgrounds of irrigation workers, titbits of knowledge from locals or their guides, folklore and stories about the origin of the water landscape, state of an area they are passing through, etcetera. Most of these accounts are published in books and are available in university or historical libraries. Some unpublished or less widespread summary reports are often only accessible in libraries and archives. A noteworthy mention is the Japanese Digital Silk Road project in the Digital Archive of Toyo Bunko Rare books, that has free scans available of over 245 rare books concerning the Silk Road and Central Asia (https://dsr.nii.ac.jp/toyobunko/index.html. en). Interesting collections can also be found elsewhere, such as the archives of Musée Guimet in Paris (France) which is included in the Catalogue Collectif des Bibliothèques des Musées Nationaux (https://ccbmn.culture.fr/F?RN=674417602), the British Library (https://www.bl.uk/), KADOC in Leuven (Belgium), the Swedish National Archives in Stockholm (Sweden), etc.

\section{Historical criticism}

One should keep in mind that these reports are subjective sources. The author is often not the primary source. One has heard it from someone or had to get it translated through an interpreter. This allows for the propagation of mistakes (Howell and Prevenier 2001; Boone 2015). Secondly, even if the author saw a phenomenon or feature by himself, he interpreted it according to his knowledge and world views at the time. This criticism should always be on the forefront when reading old reports. The description is, at best, a partial representation of the truth. The researchers should always ask themselves "Does this make sense? Could the author have accessed this information in the past? In what way? Are other interpretations, explanations or views possible?"(Howell and Prevenier 2001; Boone 2015). For example, Finnish explorer and Russian army secret intelligence-officer Carl Gustaf Emil Mannerheim gave a general description of houses, inhabitants and number of karez per town, when he passed through the area in 1906-1908 (Table 1). While he had no means to conduct a true census, the list gives a glimpse of some karez distribution patterns at the time. He did not specify what he defined as a karez and his toponyms and counts should not be considered correct nor absolute (Mannerheim 1969). Once again, the absence of a record does not mean the absence of a feature. Nevertheless, a lot can be gained from these sources. The German explorer Albert von Le Coq, for example, wrote how the prince (wang) from Lukchun had ordered a new karez to be built and hired some workmen from Hami to do it (von Le Coq 1926). This reveals something about the instigator for karez construction and the organization of labour.

\section{Historical satellite imagery: Corona KH-4B}

The KeyHole-4B imagery from the American Corona Spy satellite program was operational between September 1967 and May 1972 and did a total of 16 successful flights. The 
Table 1 Table of registration of Turpan villages as reported by Mannerheim

\begin{tabular}{|c|c|c|c|}
\hline Village & Houses & Inhabitants & Karez \\
\hline Yar Khoto & 100 & 400 & \\
\hline Yar & 150 & 800 & \\
\hline Kurutka & 10 & 20 & \\
\hline Buluynk & 300 & 1000 & \\
\hline Bagra & 120 & 600 & \\
\hline Yangi mähällä & 20 & 30 & \\
\hline Chatkal & 400 & 1500 & 30 \\
\hline Turpan kre & 250 & 1000 & 20 \\
\hline Erh-gung & 250 & 1200 & 25 \\
\hline Yangi shahr & 150 & 400 & 10 \\
\hline Yar bashi & 250 & 1200 & 20 \\
\hline Dji & 60 & 300 & 5 \\
\hline Löziun & 120 & 500 & \\
\hline Paka bulaq and Togung & 150 & 450 & 8 \\
\hline Yämshi and Yämshi karys & 200 & 1000 & 10 \\
\hline Qara Khoja & 1100 & $3500-4000$ & \\
\hline Astana & $\begin{array}{l}800 \\
\text { (15 shops, } 2 \text { of } \\
\text { which Andijan) }\end{array}$ & 3500 & \\
\hline Sengim & 150 & 500 & 15 \\
\hline Murtuk & 150 & 450 & \\
\hline
\end{tabular}

Many of the toponomys are interpretations by Mannerheim himself and the numbers should also be used with regards to historical criticism (Mannerheim 1969, 352-353)

films were dropped down in capsules and processed to produce images of mainly the Soviet Union and China, with a LOS resolution of some $0.8 \mathrm{~m}$. Forward- and a backward-looking cameras with an offset of $(-) 15^{\circ}$ have been used for stereographic purposes (Auelmann 2015). The images of the Corona spy satellite missions were declassified in 1995 by Executive Order 12,951 (Ruffner 1995; Auelmann 2015). They can be ordered (if yet un-digitized) or consulted on the Earth Explorer Web application (https://earthexplorer.usgs.gov/). In the present case study, the images of the study area were ordered as a 7-micron downloadable scan to preserve the highest possible resolution. The images were taken in August 1968 and both the forward and backward images were acquired. This is useful to check certain over- or -under-lighted features and is necessary for producing a terrain model.

\section{Processing method}

Ideally, GCP measurements (Ground Control Points) have to be available for the area, so that the satellite-images can be ortho-rectified. This technique has been applied in several manners by many authors (Schmidt et al. 2001; Altmaier and Kany 2002; Gheyle et al. 2004; Goossens et al. 2006; Beck et al. 2007; Galiatsatos et al. 2008; Casana and Cothren 2013; Ur 2013; Watanabe et al. 2017). If fieldwork or GCP measurements are not possible, there are two remaining options. One is using other data to extract the parameters, horizontal coordinates and elevation data. This is described by Galiatsatos et al. (2008), 
who used IKONOS imagery, a SRTM DEM and Syrian elevation maps to geo-reference Corona images. The goal was to extract elevation data from the Corona stereo-pairs. This gave good results, but can be quite time-consuming. Another option is only extracting the horizontal coordinates from secondary satellite imagery and not the vertical reference. This prevents the possibility of creating a DEM and correcting deformations due to elevation. Because of the lack of high-resolution elevation data and the fact that vertical references

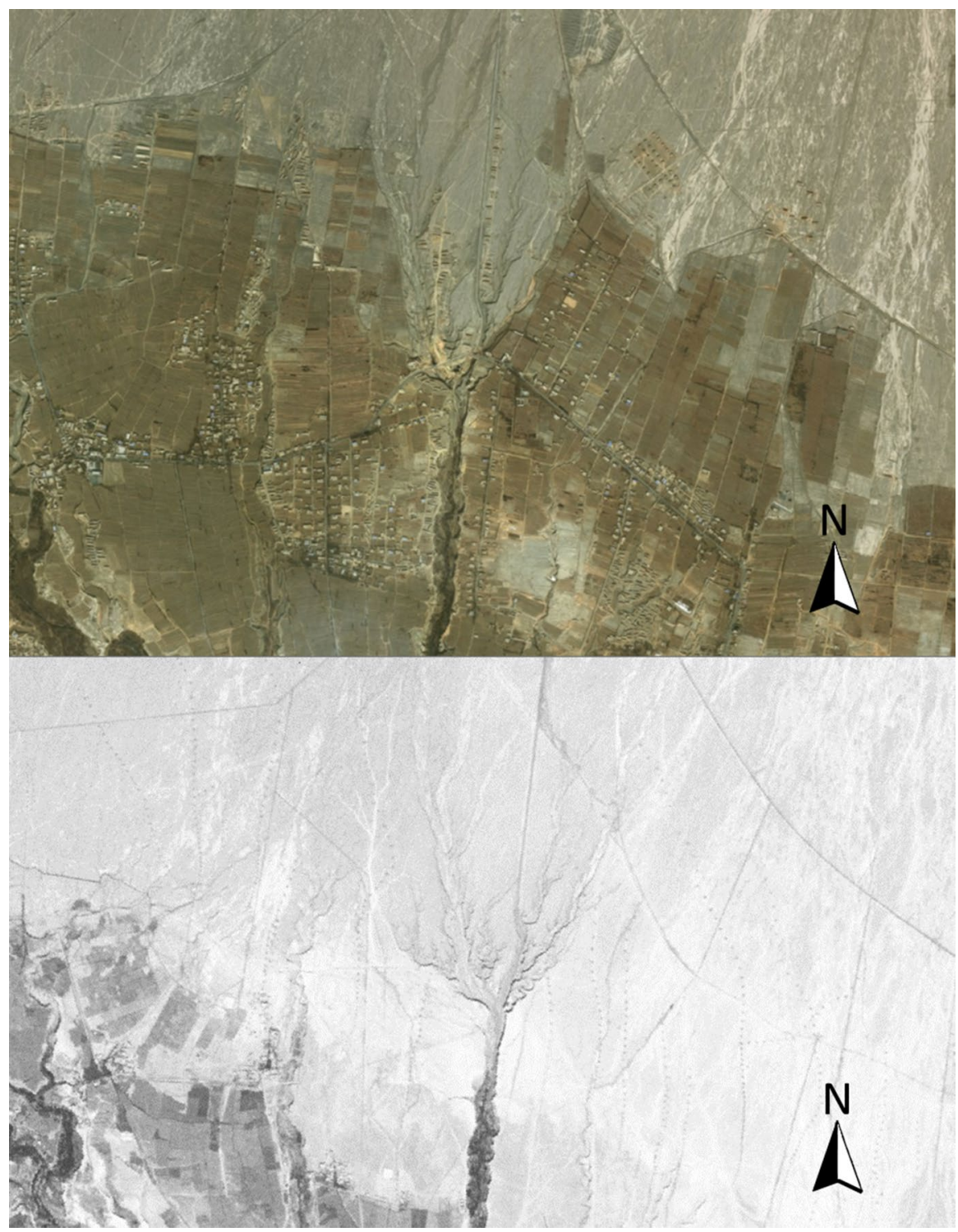

Fig. 8 Comparison of a modern view of the landscape north of Murtuq in Turpan on the Corona KH-4B satellite imagery (under) and the Esri Satellite basemap (above). Several karez lines, roughly running north-south are visible and the destruction by the agricultural expansion is evident (USGS Corona Imagery, Esri Basemap) 
are not detrimental for recognizing karez, the second option is chosen out of necessity. It is sufficient to manually reference the images on an already existing satellite image. The image was stretched; some small errors are unavoidable, but if done well, it will still allow for the interpretation of past landscapes. The referencing is realised in ArcMap 10.3 based on the standard base map provided by Esri.

If the images are well-chosen (unclouded, good lighting, well-developed and a quality scan), the resolution is good enough to see separate karez wells and karez lines in most areas (Fig. 8). The KH-4B-images predate most modern landscape development in the region and thus enable information gathering concerning the expansion of agriculture, the general landscape lay-out, old waterways and water bodies, and the distribution and density of karez. Still functioning karez cannot be built closer than $500 \mathrm{~m}$ from other groundwater exploitation systems, because they will drain the water (Banks and Soldal 2002). So many karez lines in the vicinity of others can (must?) be interpreted as several generations of one karez line that had to be repaired or replaced.

\section{Miscellaneous}

Finally, we should mention the many miscellaneous sources that do not fall into any of the above categories. One category groups manuscripts that contain direct or indirect information. For example, old water system management, water feature location or past agricultural uses are sometimes mentioned (Trombert 2002, 2008; Barbaix 2018). Manuscripts have been used to reconstruct the Amaniel qanat in Spain (Martínez-Santos and MartínezAlfaro 2014). Trombert went through old manuscripts of the Gaochang Kingdom and Tang dynasty era to trace irrigation and waterworks at the time (Trombert 2008). Myths, stories, poems and songs reveal something about traditions, but folklore connected to the karez are often overlooked (Yakup 2005). All these sources tell something about the historic importance of water and karez, certain functions and legislations in the past and the existence or possible absence of certain features.

\section{Conclusion}

Many diverse, but nonetheless relevant pieces of information can be gleaned from historical sources as we illustrated above. While some sources are straightforward in their usefulness, others are trickier. The examples of processing methods provided and the data extracted show the potential of this research approach. For example, the comparison between old and modern landscape photographs in GIS or the critical digitization of ancient maps gave insight into how these techniques and sources provided either basic or circumstantial information. Especially in cases where primary sources are rare or hard to access, as is the case for Turpan, these type of sources can fill in some gaps and provide added value to the research. We hope to inspire others to look at obvious and less obvious historical sources when researching water landscapes.

Acknowledgements We are very grateful to the University of Chinese Academy of Sciences (UCAS) for the Scholarship awarded CAS-TWAS President's Fellowship Programme for International Doctoral Students. Special thanks are also in order for Mr. Guo Zengkun and Mr. Abdimijit Ablekim for their assistance in the fieldwork. 
Author Contributions All authors contributed to the study conception and design. SB, JB, AK and PDM material preparation, data collection and analysis were performed. The first draft of the manuscript was written by Sophie Barbaix and all authors commented on previous versions of the manuscript. All authors read and approved the final manuscript.

Funding This research was jointly funded by the Strategic Priority Research Program of Chinese Academy of Sciences (Grant No. XDA20060303) and by the Chinese Academy of Sciences President's International Fellowship Initiative (PIFI, Grant No. 20188048, 2017VCA0002, 2020VCA0015), and the Ghent University Department of Archaeology-Research Fund.

Data Availability Not applicable.

Code Availability Not applicable.

\section{Compliance with ethical standards}

Conflict of interest The authors declare that there are no conflict of interest.

\section{References}

Aihua M (2015) Causes of geotechnical engineering diseases of karez in Turpan and revelation of their prevention and restoration. In: Tolmbok GN (ed) Collected Papers on the Study of Karez in Xinjiang. Xinjiang Karez Study Society of Xinjiang Uyghur Autonomous Region, Urumqi, pp 306-312

Altmaier A, Kany C (2002) Digital surface model generation from CORONA satellite images. ISPRS J Photogramm Remote Sens 56:221-235. https://doi.org/10.1016/S0924-2716(02)00046-1

Auelmann RR (2015) Corona KH-4B Satellites. https://www.nrsc.gov.in/sites/default/files/pdf/foreigndata/ corona.pdf.

Banks D, Soldal O (2002) Towards a policy for sustainable use of groundwater by non-governmental organisations in Afghanistan. Hydrogeol J 10:377-392. https://doi.org/10.1007/s10040-002-0203-y

Barbaix S (2018) The Water Landscape of Murtuq. An Analysis and Interpretation through Landscape Studies. Masterpaper Ghent University

Beck A, Philip G, Abdulkarim M, Donoghue D (2007) Evaluation of Corona and Ikonos high resolution satellite imagery for archaeological prospection in western Syria. Antiquity 81:161-175. https://doi. org/10.1017/S0003598X00094916

Bertrand A (2010) The hydraulic systems in Turfan (Xinjiang). Silk Road 8:27-41

Boone M (2015) Historici en hun métier. Een inleiding tot de historische kritiek, Academia Press, Gent

Cabos M (2018) Creating heritage and the mission Paul Pelliot : early photography of Dunhuang and their legacy. Chinese Hist Rev 25:97-117. https://doi.org/10.1080/1547402X.2018.1522817

Casana J, Cothren J (2013) The CORONA Atlas Project : Orthorectification of CORONA Satellite Imagery and Regional-Scale Archaeological Exploration in the Near East. In: Comer DC, Harrower MJ (eds) Mapping Archaeological Landscapes from Space. SpringerBriefs in Archaeology, Springer, New York, pp 31-41

Dreyer C (2008) Die Expeditionen der Russen auf der Seidenstraße. In: Trümpler C (ed) Das große Spiel: Archäologie und Politik zur Zeit des Kolonialismus (1860-1940). DuMont, Essen, pp 178-187

Evans JG (2003) Environmental archaeology and the social order. Routledge, London. https://doi. org/10.4324/9780203711767

Falconer J (2004) Perspectives on Photography's Contribution to Archaeology in Central Asia. In: Agnew N (ed) Proceedings of The Second International Conference on the conservation of Grotto Sites: Conservation of Ancient Sites on the Silk Road. The Getty Conservation Institute, Los Angeles, pp 107-116

Fu R, Shadeer M, Tiyipujiang R (2014) Study Breaking mechanism of Karez Systems in Turpan Basin. Procedia Mater Sci 3:1786-1791. https://doi.org/10.1016/j.mspro.2014.06.288

Galiatsatos N, Donoghue DNM, Philip G (2008) High Resolution Elevation Data derived from Stereoscopic Corona Imagery with minimal Ground Control: an Approach using Ikonos and SRTM data. Photogramm Eng Remote Sens 74:1093-1106

Gheyle W, Trommelmans R, Bourgeois J et al (2004) Evaluating CORONA: a case study in the Altai Republic (South Siberia). Antiquity 78:391-403. https://doi.org/10.1017/S0003598X00113031 
Goossens R, De Wulf A, Bourgeois J et al (2006) Satellite imagery and archaeology, the example of CORONA in the Altai Mountains. J Archaeol Sci 33:745-755

Howard P, Thompson I, Waterton E, Atha M (2019) The Routledge Companion to Landscape Studies, second. Routledge, London. https://doi.org/10.4324/9781315195063

Howell MC, Prevenier W (2001) From reliable sources: an introduction to historical method. Corbell University Press, Ithica

Hu W, Zhang J, Liu Y (2012) The qanats of Xinjiang: historical development, characteristics and modern implications for environmental protection. J Arid Land 4:211-220. https://doi.org/10.3724/ SP.J.1227.2012.00211

Huang W (1954) 吐魯番考古記 (Archaeological Report in Turfan). Science Press, Beijing

Jarring G (1997) Central Asian Turkic place-names: Lop Nor and Tarim area: an attempt at classification and explanation based on Sven Hedin's diaries and published works. Sven Hedin Foundation, National Museum of Etnography, Stockholm

Jarring G (1961) Some notes on Central Asian Turkic place names. Bull Geol Inst Univ Uppsala 40:467-478

Jenny B (2006) MapAnalyst - A digital tool for the analysis of the planimetric accuracy of historical maps. e-Perimetron 1:239-245

Lai HH (2002) China's Western development program: its rationale, implementation, and prospects. Mod China 28:432-466. https://doi.org/10.1177/009770040202800402

Liu Y, Tian F, Hu H, Sivapalan M (2014) Socio-hydrologic perspectives of the co-evolution of humans and water in the Tarim River basin, Western China: the Taiji-Tire model. Hydrol Earth Syst Sci 18:12891303. https://doi.org/10.5194/hess-18-1289-2014

Lombard P (1991) Du rythme naturel au rythme humain : vie et mort d'une technique traditionnelle, le qanat. MOM Éditions 20:69-86

Mannerheim CG (1969) Across Asia: from West to East in 1906-1908. Oosterhout, Netherlands

Martínez-Santos P, Martínez-Alfaro PE (2014) A priori mapping of historical water-supply galleries based on archive records and sparse material remains. An application to the Amaniel qanat (Madrid, Spain ). J Cult Herit 15:656-664. https://doi.org/10.1016/j.culher.2013.12.003

Massey D (2005) For space. SAGE Publications Ltd, London

Matsui D (2015) Old Uyghur toponyms of the Turfan oases. In: Ragagnin E, Wilkens J, Silfeler G (eds) Kutadgu Nom Bitig. Festschrift für Jens Peter Laut zum 60. Geburtstag. Harrassowitz Verlag Wiesbaden, Wiesbaden, pp 275-303

Mingjiang D (2015) Karez wells in arid land and mountain-front depressed ground reservoir. In: Tolmbok GN (ed) Collected papers on the study of Karez in Xinjiang. Xinjiang Karez Study Society of Xinjiang Uyghur Autonomous Region, Urumqi, pp 193-210

Mostafaeipour M (2010) Historical backgrounds, productivity and technical issues of qanats. Water Hist 2:61-80. https://doi.org/10.1007/s12685-010-0018-z

Petrie CA, Orengo HA, Green AS et al (2019) Mapping archaeology while mapping an empire : using historical maps to reconstruct ancient settlement landscapes in modern India and Pakistan. Geosciences 9:1-26. https://doi.org/10.3390/geosciences9010011

Ruffner KC (1995) CORONA. America's first satellite program. Central Intelligence Agency Center for the Study of Intelligence, Washington DC

Saunders N (2009) Ulysses' gaze: the panoptic premise in aerial photography and Great War archaeology. In: Stichelbaut B, Bourgeois J, Saunders N, Chielens P (eds) Images of conflict: military aerial photography and archaeology. Cambridge Scholars Publishing, Newcastle upon Tyne, pp 27-40

Schmidt M, Menz G, Goossens R (2001) Processing techniques for CORONA satellite images in order to generate high-resolution digital elevation models (DEM). In: Proceedings of the 21 EARSeL Symposium,pp 191-196

Stein MA (1928) Innermost Asia. Detailed Report of Explorations in Central Asia, Kan-su and Eastern Iran: vol.3 Plates and Plans. Clarendon Press, Oxford

Tolmbok GN (2015) Collected papers on the study of Karez in Xinjiang. Xinjiang Karez Study Society of Xinjiang Uyghur Autonomous Region, Urumqi

Trombert É (2008) The karez concept in ancient Chinese sources: myth or reality? T'oung Pao 94:115-150. https://doi.org/10.1163/008254308X367031

Trombert É (2002) Les cycles de culture et l'organisation des terroirs à Tourfan aux VIe -VIIIe siècles. Bull Ec Fr Extr Orient 89:203-235. https://doi.org/10.3406/befeo.2002.3567

Ur J (2013) Spying on the past: declassified intelligence satellite photographs and near eastern landscapes. Near East Archaeol 76:28-36. https://doi.org/10.5615/neareastarch.76.1.0028

von Le Coq (1926) Auf Hellas Spuren in Ostturkestan: Berichte und Abenteuer der II und der III. Deutschen Turfan-Expedition. J. C. Hinrichs'sche Buchhandlung, Berlin 
Watanabe N, Nakamura S, Liu B, Wang N (2017) Utilization of structure from motion for processing CORONA satellite images : application to mapping and interpretation of archaeological features in Liangzhu culture, China. Archaeol Res Asia 11:38-50. https://doi.org/10.1016/j.ara.2017.06.001

Yakup A (2005) The Turfan dialect of Uyghur. Harrassowitz, Wiesbaden

\section{Historical Sources used for Map Regression of Waterways}

Huang W (1954b) 吐魯番考古記(Archaeological Report in Turfan). Science Press, Beijing

Klementz D (1899) Turfan und seine Altertümer. In Nachrichten über die von der Kaiserlichen Akademie der Wissenschaften zu St. Petersburg im Jahre 1898 ausgerüstete Expedition nach Turfan. Heft 1. St. Petersburg

Stein MA (1921) Serindia. Detailed report of explorations in Central Asia and Westernmost China. vol.5 Maps. Oxford University Press, Oxford https://doi.org/10.20676/00000183

Stein MA (1928c) Innermost Asia. Detailed report of explorations in Central Asia, Kan-Su and Eastern Iran: Vol.3 plates and plans Clarendon Press Oxford https://doi.org/10.20676/00000187

Von Le Coq (1923) Die Buddhistische Spätantike in Mittelasien Ergebnisse der Kgl. Preussischen TurfanExpeditionen Verlag Dietrich Ernst Vohsen, Berlin

Publisher's Note Springer Nature remains neutral with regard to jurisdictional claims in published maps and institutional affiliations.

Sophie Barbaix is a joint $\mathrm{PhD}$ candidate at the Xinjiang Institute of Ecology and Geography (Departement of GIS and Cartography) and at Ghent University (Department of Archaeology). She first conducted research in Xinjiang in 2017. In 2018 Sophie was selected by the CAS-TWAS President's Fellowship Programme for International Doctoral Students and joined the Sino-Belgian Joint Laboratory for Geo-Information. Her work is alternately based in China and Belgium.

Alishir Kurban is a professor at the Xinjiang Institute of Ecology and Geography, Chinese Academy of Science. His research interestings including application of remote sensing and geographic information techcnology in the field of arid environment and ecosystem research. Special focused on natural resource mapping, land cover and land use mapping, vegetation mapping and urban mapping via applying remote sensing and GIS. He also tested new 3 dimentional modeling technology for archeological site erosion research and 3 dimensional change detection of arid land surface including vegetation above biomass changes. He made over 30 variety scales thematic maps including land cover/land use maps, vegetation maps, natural resources maps for the Xinjiang Region, published over 50 research papers in scientific journals in Uyghur, Chinese and English. He supervised and co-supervised over $30 \mathrm{MSc}$ and $\mathrm{PhD}$ dissertations. He successfully organized or co-organized several international scientific conferences and summer schools in field of Cartography and GIS. Intercarto-InterGIS 14, GISCA and SilkGIS series conference in Urumqi, Bishkek, Tashkent and Isfahan.

Philippe De Maeyer is senior full professor in cartography and GIS at Ghent University (Belgium). In 19811987 he was active in development cooperation, in 1987 he moved to a company as manager of a department of geographical information and in 1999 he joined Ghent University. He served from 2008 on during 12 years as the chair of the department of geography. He is also visiting professor at the Xinjiang Institute of Ecology and Geography. His research focuses on flood risk calculation, 2D and 3D data modelling, and land cover/land use change mapping in Central Asia. Philippe De Maeyer was the chair of the Belgian National Committee for Geography (2011-2018) and is presently vice-president of the International Cartographic Association.

Xi Chen is a professor at the Xinjiang Institute of Ecology and Geography, Chinese Academy of Sciences, and the General Director of the Research Center for Ecology and Environment of Central Asia. His research focuses on remote sensing and geographical information systems, hydrology and water resources in arid land. Outstanding scientific research results have been achieved in the assessment of the ecosystem of Central Asia, land use and land cover change in arid areas, and water resources management in the Aral Sea and the Tarim River basin. He is the chairman of the Ecosystem Monitoring and Research Alliance of Central Asia. 
Jean Bourgeois is currently senior full professor at the Department of Archaeology of Ghent University. He studied History and Archaeology (1973-1978) at Ghent University. His research topics are mainly concentrated on the Bronze and the Iron Age, and on landscape archaeology. As Bronze and Iron Age is concerned, he was active as well in Flanders-aerial photography (funerary landscapes of barrows) and excavations (burial monuments, settlements) as in Central Asia (landscape archaeology, archaeological survey, mapping, remote sensing using satellite imagery, GPS-technology, GIS and some excavations). Since many years he is also active in the Russian Altai Mountains (1995-2015) and in the Turpan area (Xinjiang, China) (2010-now). 